\title{
初期クメール複合寺院，プラサート・サンボーの改変 ALTERATION OF AN EARLY KHMER TEMPLE COMPLEX, PRASAT SAMBOR
}

\author{
下田一太*, 中川武** \\ Ichita SHIMODA and Takeshi NAKAGAWA
}

\begin{abstract}
Prasat Sambor is one of the main temple complex in the Khmer ancient city, Isanapura. Two different periods of inscriptions that indicate 7 th and 10th century have been confirmed in this temple up to now. In addition, previous studies on the style of stone sculptures, architectural decorative elements and excavated artifacts also interpreted the various date from 7th century when it was constructed at earliest stage to late Angkor period. By the recent archaeological excavation survey, many alteration traces of the buildings were recognized. Especially, there are double structures were found under the east gate of middle enclosure, and original temple design was conjectured different from final phase. This paper discussed on the transition of the alteration of this temple complex.
\end{abstract}

Keywords: Cambodia, Khmer, Pre Angkor, Sambor Prei Kuk, Isanapura

カンボジア, クメール, プレアンコール, サンボー・プレイ・クック, イーシャナプラ

\section{1. はじめに}

カンボジアの国土のほぼ中央に位置するサンボー・プレイ・クッ ク遺跡群（Sambor Prei Kuk）は，アンコール王朝の前身国家である チェンラ王朝の首都，イーシャナプラ（Īçānapura）に比定されてお り，7世紀初頭に創建された多数の煉瓦造寺院や都城址が含まれる。 中でも，プラサート・イエイ・ポアン (Prasat Yeai Poeun) とプラサ ート・サンボー（PrasatSambor）は，それまでのクメール建築と比し て, 飛躍的な伽藍配置構成の発展を遂げ, アンコール時代に一般化 寸る複合的な伽藍形式の萌芽をなす寺院として注目される。

これらの寺院はアンコール王朝が創設された9世紀以降にも, 放置 されることなく「生きた」寺院として長期間にわたり利用され続け たことが過去の研究によって指摘されている。遺跡群東方の寺院が 集中する地区の南側に位置するプラサート・イエイ・ポアンでは, 過去にフランス極東学院の研究者らにより, 伽藍内の発掘調查が行 われた。寺院内のある祠堂からは, 西暦627年にリンガが奉納され た，という実年代を含む碑文が発見された他，イーシャナヴァルマ ン (İsānavarman）一世の治世期（616-635?）の碑文が複数出土して いる。こうした建立当初のものと考えられる碑文の発見と同時に, 10～11世紀の作品と推測されるガネーシャ像や，さらに時代が下っ てバイヨン期の神像も併せて出土している11。

一方, 寺院集中地区の北側に位置するプラサート・サンボーでも また，碑文学者フィ（L. Finot）が指摘するように，そこには確か に7世紀と10世紀の「二つの時代」の痕跡が併存する ${ }^{2)}$ 。碑文史料に 基づく年代観に限らず，この寺院から発見された彫刻作品の美術様 式や, 発掘の出土品に含まれる中国産陶磁器等にも, 建立当初の7世
紀とは異なる時代を示す遺物が含まれている3)。こうした事実と符合 するように, 近年プラサート・サンボーにおいて実施した発掘調査 からは，建築遺構の増改築の痕跡が複数確認された。

本稿は，こうしたプラサート・サンボーにみられる年代指標とな りうる史的痕跡を整理した上で，2001年以降に実施した発掘調查 ${ }^{4}$ に より確認された遺構の改変痕から, 伽藍増改築の推移の一端を明ら かにしようとするものである。

\section{2. プラサート・サンボーの伽藍配置構成}

プラサート・サンボーは二重の周壁に囲繞された寺院としてこれ まで認識されてきたが，最近の調查により，外側にさらにもう一重 の周壁が存在した痕跡が発見され, 主祠堂を中心として, 複数の祠 堂を布置し, 三重の周壁に囲繞された伽藍配置構成をなしていたこ とが明らかになっている5)。最外郭の外周壁は一辺約 $389 \mathrm{~m} の$ 方形平 面を囲い, さらにその周囲には環濠らしき起伏も認められ ( $^{6)}$, 遺跡 群の中でも最も大きな寺域を有する。

本稿では, 三重の周壁を外から内に向かって外周壁, 中周壁, そ して内周壁と称するが，それらの周壁の配置は，典型的なクメール 寺院とは異なっている。つまり, クメールの複合寺院では, 主祠堂 を矩形の周壁に囲繞された敷地のほぼ中心か, 後方に配しているの が一般的であるのに対して, 本伽藍では主祠堂を中心に配する内周 壁が中周壁内において前方，つまり東方に偏っている上，中周壁は 外周壁の中心から大きく南東方向に偏位している（図1）。このよ うに，外周壁が伽藍を北西側に大きく広げるように配置されている のは, 寺院の東側に迫る河川の氾濫原や，既存の周辺寺院の敷地を

\footnotetext{
* 早稲田大学理工学術院総合研究所 講師 · 修

Visiting Assistant Prof., Advanced Research Institute for Science and Engineering, Waseda

***早稲田大学理工学術院 教授. 工博 
避けるように, 後世に伽藍が拡張されたためであったものと推測さ れ, 後述する発掘調查により明らかとなった外周壁の後補に関する 推測とも合致する。

また，中周壁を含むその内側の各祠堂や周壁は極めて高い精度で 四方対称に配置されているにもかかわらず，外周壁の平面には歪み がみられ, 測量配置や施工精度が劣っていることも, 外周壁が後世 になってから増築され，伽藍規模が拡張されたことを示唆するもの と考えられる。

\section{3. プラサート・サンボーの年代観}

クメール建築の年代考察には，碑文史料や，建築や彫刻装飾の様 式編年, 出土遺物の年代判定などが有用であるが，プラサート・サ ンボーにお颃従来の研究では, そうした年代推定要素のいずれも が, プレ・アンコール時代に限らず, より広い時代的分布を示して いる。以下に, 最近の発掘調查による新たな知見を交えて, それら を整理したい。

\section{1 碑文史料にみられる年代}

遺跡群全域でこれまでに確認されている碑文は合計 24 点に上 る。うち21点はルクレール（A. Leclère），ラジョンキエール（E. L. de Lajonquiere) , モーラン（G. Morand）, パルマンティエ（H. Parmentier)，そしてゴルベウ（V. Goloubew）によって19世紀末か ら20世紀前半に発見された碑文であり，残り3点は1998年以降に我 々の調查により発見されたものである。それらのうち，実年代を記 しているものはわずかに 3 点のみで, 最古のものは, 遺跡群北方に位 置するスレイ・クルップ・リアク（Srei Krup Leak）寺院群から出土 した碑文K.1517であり，598年を刻む。続いて，プラサート・イエイ ・ポアンから出土した 627 年の碑文K.604 ${ }^{8)}$, そして北方に位置するロ ーバン・ロミアス（Robang Romeas）寺院群の碑文K.1539)に記された 1001年が最も新しい。これら以外の碑文についても, 記された王名 等からその大半は時代推定が可能である。

プラサート・サンボーの寺域内からは，5点の碑文が発見されて

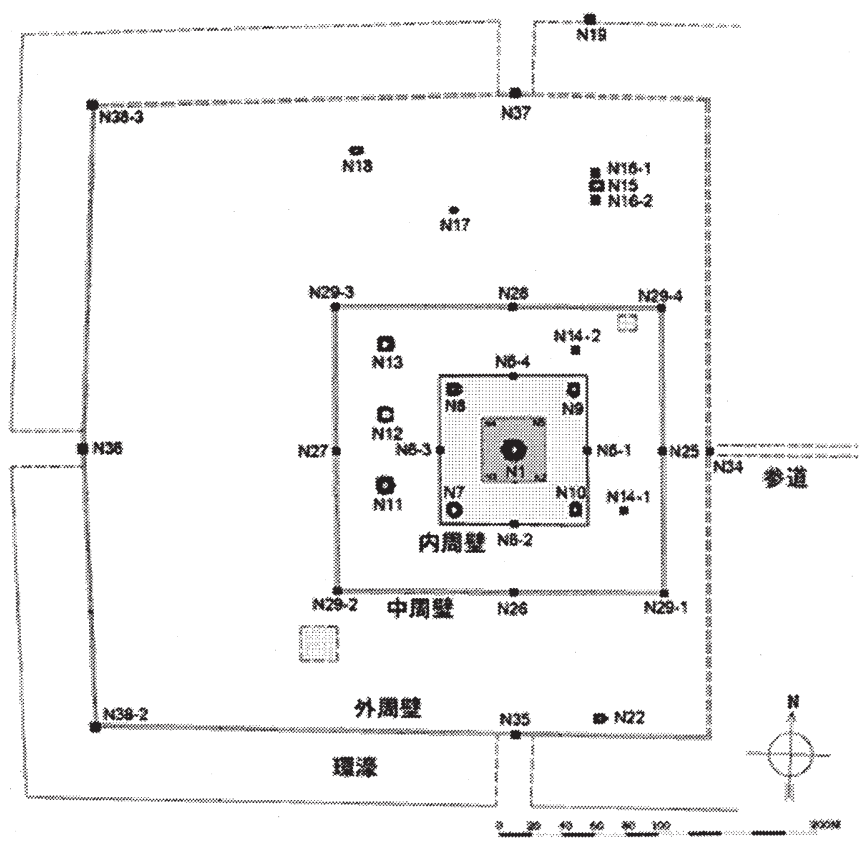

図1 プラサート・サンボー寺院配置図
いる。N15塔のK.148碑文，N18塔のK.149碑文，中周壁の東門である N25塔のK.436碑文，N14-1塔のK.437碑文，そしてN16塔(N16-1塔と N16-2塔のどちらかは不明）のK.438碑文である。これらの碑文のう ち, K.149, K.437, K.438はイーシャナヴァルマン一世の名を記して おり，彼の治世期である7世紀初頭の碑文であると考えられている。 他方，K.148とK.436は10世紀の碑文に比定されている。

これらの碑文と漢籍史料の記述から, 当寺院は建立当初の時点 ではBhadreçvara神を祀っていた可能性が高いこと年，また10世紀 に入ると，ラージェンドラヴァルマン（Rajendravarman）二世によ り Gambhireçvara神を主尊とした寺院に改宗されたことが推測され ている ${ }^{11)}$ 。

ここに示された両神格は，シヴァ派の尊格であるが，初代の主尊 Bhadreçvara神はプレ・アンコール期に広く流布した守護神として知 られている。近年実施した主祠堂内外の考古学的調查からも，プラ サート・サンボーがシヴァ教の寺院であったことを裏付ける遺物が 確認された。主祠堂の周囲のクリアランス調查と, 主祠堂内部の発 掘調查によって出土した砂岩片を繋ぎ合わせたところ，一辺 $2.7 \mathrm{~m} の$ 方形台座が復元され, 出土地点とその規模から, 当初は主祠堂内に 配されていた台座であることが推測された。この台座の中央には, 直径 $1.2 \mathrm{~m}$ の形の柄穴が穿たれており，ここにはシヴァ信仰の象徵 であるリンガが据えられていたものと推測されるのである ${ }^{12)}$ 。

例えば，アンコール期初頭の寺院であるプノン・ボックには直径

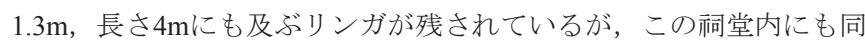
等の規模と威容を誇るリンガが安置されていた様子を偲ぶこともで きる。はたして，10世紀におきた同じシヴァ派間での改修の際に， リンガの据え換えが生じたから゙うかは定かではないが，このリンガ の受け穴が穿たれた台座の発見は，寺院の主尊であるBhadreçvara神 ならびにGambhireçvara神の象徵をなすリンガが，寺院の主祠堂に祀 られていたことを示唆するものである。

\section{2 彫像の様式にみられる年代観}

寺院の各祠堂内には, 当初, 神像が安置されていたものと考えら れるが, 残念ながらその大半は遺失している。当遺跡群から発見さ れた彫像は4体にすぎないが，それらはいずれもプラサート・サンボ 一から発見されたものである。碑文史料と同じく，それら彫像の美 術様式もまた，7世紀と10世紀の二つの時代を示している。

ハリハラ（Harihara）神像は，プラサート・サンボーの副祠堂で あるN10塔と, 当寺院群の北東に位置するサンボー村の精霊信仰の 祠の二箇所から，50以上の小片となって破壊された状態で発見され $た^{13)}$ 。現在，この彫像は修復されて，プノンペン国立博物館に展示 されているが，彫像を支持する柄の形状と，N10塔の室内に残存する 台座上面の柄穴の形状とが一致したことより, 原位置はN10塔であ ったことが確認された。この彫像は美術様式の編年に基づき，7世 紀前半のサンボー様式に分類されている ${ }^{14)}$ 。

ドゥルガー（Durga）神像もまた，主祠堂であるN1塔と，副祠堂 N9塔の二箇所から破壊された各部が発見されている。プレ・アンコ 一ル期の女神像を代表する作品で，頭と両手を欠くトルソーの彫像 である。N1塔から彫像の一部が発見されたのが，N9塔における発見 よりも約半世紀先行したため, 長きに渡り, この彫像はN1塔に安置 されていたものと考えられていた。しかしながら, 前述の通りN1塔 
内に円形の穴が穿たれた大型の台座が発見されたため，等身大規模 のドゥルガー神像が, ここに安置されていた可能性はほぼ否定され ることとなった。一方，N9塔室内にドゥルガー神像を安置していた 台座は残っておらず，2005年に実施した塔内の発掘調查からも，台 座片は一切検出されなかった。N9塔以外の他の祠堂内において, 近 年復元されたいずれの台座 $\left.{ }^{15}\right)$ の柄穴もまた，ドゥルガー神像のもの とは一致しないため, ドゥルガー神像の一部が発見されたN9塔が原 位置であった可能性は高い。ドゥルガー神像も美術様式の編年によ りサンボー様式に分類されている16)。

N22塔の付近からはブラフマー（Brahma）神像が発見されてい る。この神像は, 脚部を紛失しているために, 台座の柄穴との照合 は不可能であるが，塔内に確認されている二組の台座はいずれも小 型のものであり ${ }^{17)}$, ブラフマー神像もまた小振りであることから， これらの台座に安置されていたことが推測される。この彫像はプレ ・アンコール期の一様式であるプレイ・クメン様式に分類されてい る ${ }^{18)}$ 。ただし, 彫像そのものの様式編年によるものではなく, 後述 する同塔のリンテル装飾の様式編年に彫像の編年が依拠するもので あることに注意を要する。

これら3体のサンボー様式の神像に加えて，2005年に発掘調查を実 施したN14-2塔の室内からは, 完形のリンガ・ヨーニの御神体が出土 した。ここで発見されたリンガは, 先太りの砲弾型をしたものであ り, アンコール期に典型的なリンガとは異なる。当遺跡群からは, 他にもこの形式のリンガが数点発見されており, プレ・アンコール 期に特有の様式であると考えられているが，こうして台座と対にな る出土例は初めてである。リンガを類型学的に整理した様式編年は 十分に確立されていないが，これがプレ・アンコール期の安置物で あることはほぼ明らかである。

このように, 点数は限られているものの, プレ・アンコール期, 中でもサンボー様式に分類される彫像が, 発見された神像の大半を 占める中で, 副祠堂であるN7塔室内から発見されたとされるヴァジ ムカ（Vajimukha）神像は, 10世紀, アンコール時代のプレ・ルプ 様式を示している ${ }^{19)}$ 。台座は円形の砂岩材5層積みよりなり, 最下 層は直径 $3.13 \mathrm{~m}$ の大型の石材からなる ${ }^{20)}$ 。この台座の最上層には安 置されていた彫像を支えるための柄穴が穿たれているが, 現在, パリのギメ博物館に展示されているこの彫像は, 足回りが久損し ており, 台座の恼穴との照合は今となっては不可能であるため, 厳密にはこの神像の原位置がN7塔であったことについては疑問符 が残されている。

\section{3 リンテル装飾の美術様式にもとづく編年}

リンテル装飾は, クメール建築の様式編年において最も有用な 建築部位の一つである。当寺院からは, N7塔, N11塔, N14-1塔, N14-2塔, N15塔, N22塔, N25塔の計7点のリンテルが確認されて いる。

これらのうち，原位置に残存するものはN22塔のみである。N11塔 のリンテルは古写真と現場倉庫に収蔵されているリンテルの照合に より明らかになったもの，N15塔のリンテルは既に剥奪されてしま ったが古写真に記録されているもの, その他のリンテルは最近の 調査で新たに発見されたものである。また, これらのリンテルの うち，N7塔, N11塔, N14-1塔, N14-2塔, N15塔のものはサンボー様式
に分類される。

N22塔のリンテルはプレイ・クメン様式に分類される。プレイ・ クメン様式はサンボー様式にやや遅れて生じた様式であるものの, 重複する時代を長く有することから，この様式の別を根拠に，N22塔 が他の塔より後に建造されたとは, 必ずしも断言できない。とはい え, この祠堂が伽藍内でも孤立して配置されていることから, 建造 に時間差があった可能性は指摘しうる。

最近の調査で発見された, 中周壁東門のN25塔のリンテルは, 未完 成であると思われるが，プレ・アンコール期の様式を示すリンテル 一と彫り進めるための, 彫刻加工の一過程で放置されたものとは考 えがたい。プレイ・クメン様式とアーチの曲線が類似しているが, アーチ上方に残された彫刻面がいささか狭すぎるように思われる。 いずれにせよ，この寺院から発見されている他のリンテルとは異な る様式を示しており, 後世の作である可能性が高い。リンテルと併 せてN25塔付近より出土したコロネットは, 円柱形で装飾彫刻はプレ ・アンコール期の特徴を示しているため, このリンテルの製作時代 とは隔たりがあると考えられる。なお，ここN25塔は 10 世紀の碑文 K.436が刻まれた扉縦枠材が出土した遺構であり, リンテルが後世 の作である可能性と呼応していることに留意されたい。

\section{4 過去の発掘遺物にみられる年代観}

遺跡群における初めての本格的な考古学的発掘調査は, ゴルベ ウの指揮の下, プラサート・イエイ・ポアンにおいて1927年に実 施されたものである。この考古学的発掘調查により, 碑文が刻ま れた扉枠, リンテル, 台座, 陶器, 陶磁器等の他, 前述したアン コール期のガルーダに跨る男性像やテラコッタ製のガネーシャが 発見された ${ }^{21)}$ 。

その後，1961年1月から2月にかけて，グロリエ(B. P. Groslier)によ る発掘調査が行われた。このときの調査は報告がないが, 非公式の 文書記録と図面, 写真が残されている22)。特にプラサート・サンボ ーとプラサート・イエイ・ポアンの両寺院間で多数の遺物が出土し たため,この区域で集中的な調査が展開された。

グロリエはこの時に発見された陶磁器に関するまとまった報告を 残さなかったが, 彼が残したクメール陶器に関する概説書の中で,

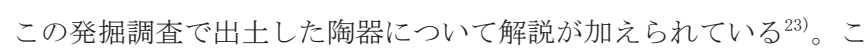
の時の出土遺物の中でも年代判定の指標となりうる中国産陶磁器を 対象に再調査を実施した ${ }^{24)}$ 。中でも年代判定を細分化しうる白磁・ 青磁の椀や皿は8世紀後半の晚唐にさかのぼる可能性があるものから 14世紀後半の元代にまで至る陶磁が連綿と続いていることが確認さ れた。特に11世紀後半以降のものが急増する傾向が見られる。中国 陶磁器が主力貿易品として対外輸出されるのは8世紀後半以降のこと であり, これ以前には中国陶磁のアジア出土例は稀少であるため, 中国陶磁を指標に年代の上限を考察することは難しいが，寺院区の 施設が少なくとも14世紀後半まで存続していることが窥われる結果 が得られた。

このように, 当寺院からは7世紀と 10 世紀の両時代を示唆する碑 文や彫像が出土しているほか, 中国陶磁も8世紀後半から14世紀後 半までの長期に渡る年代が認められたことになる。以下に, こうし た長期継続の事実と整合しうる, 発掘調査による出土遺構の改変の 様子を示したい。 


\section{4. 発掘調査により確認された改変の痕跡}

\subsection{N1塔の改変}

2001年にプラサート・サンボーの主祠堂（N1塔）周辺の堆積土砂 のクリアランスを行った ${ }^{25)}$ 。壁体の半ばまで堆積していた崩落煉瓦 や土砂を除去した結果，祠堂の一部が改変されていた痕跡が明らか となった ${ }^{26)}$ 。改変は前身遺構の基壇部と付柱を一回り拡張したもの である。ここでは後補の煉瓦積みを前身遺構にしっかりと接合させ るために，前身遺構の棟瓦面を削り取り，そこに新たな棟瓦をはめ 込んで後補の棟瓦を組積する仕事が看取される。同様の痕跡がN7塔 でも認められるが，この塔は前述のようにプレ・ルプ様式の彫像で あるヴァジムカ神像が安置されていた祠堂であり, 後年に手が加え られた痕跡が他にも認められることに留意されたい。

同時に破風飾り以上の建物上部をそっくり積み換えた可能性も窥 われた。というのも, 現在, 祠堂の屋蓋部は全壊しているが, 崩落 部が階段状に整った面をなしており，過去に人為的に屋蓋部を取り 除いて, 棟瓦を組積しなおした部分が滑り面となって崩落を促して いることが看取されるためである。

また，クリアランスにより建物の外壁面には一部で漆喰が残され ている事も確認された。漆喰は約 $10 \mathrm{~cm}$ 厚さで塗り上げられている が，棟瓦の壁面に施されているフライングパレスやモールディング などの装飾は，漆喰仕上げにより覆い隠されてしまったであろうこ とが推測される。例えば，プラサート・イエイ・ポアンS10塔のフラ イングパレスでは, 棟瓦面の彫刻は漆喰仕上げ前の粗加工となる下 作業であったことが窺われる一方，N21塔のフライングパレスでは， 棟瓦面での彫刻装飾と漆喰装飾とはデザインが異なっており, 後世 にモチーフが改変されたことが明らかである。ここ，プラサート・ サンボーの祠堂では, 確かな判断材料を欠くものの, 棟瓦面での彫 刻の完成度が高いことから，漆喰による仕上げもまた後世の改変時 の仕事であったものと推測される。

\section{2 内周壁東門とその周囲の改変}

2004年から2006年にかけて，寺院内において二列のトレンチによ る発掘調查を実施した(図2)。いずれも伽藍の東西主軸方向と平行 寸るもので，一本は主軸から $20 \mathrm{~m}$ 北側に，もう一本は主軸線上を南 壁とする発掘トレンチである。伽藍内は主要な煉瓦造寺院を除いて は, 周壁等も含めてその大半はいずれも堆積土に埋没しており, 当 初の伽藍内の構成は殆ど判らない状況であった。こうした中，北列 の発掘トレンチでは，中央テラス・内周壁・中央テラスと内周壁間 ・中周壁を対象に調查を行った。中心軸上での調查は，内周壁の東 門・中周壁の東門・周壁と中周壁間・周壁の東辺中央のテラスを調 查の対象とした。

内周壁の西門では，過去にパルマンティエにより調查が行われて おり，立面図が残されている27)。今回の調査で確認された東門は， パルマンティエの報告による西門の立面構成と類似しているもの の，一部には異なる点も見うけられた（図3）。低い連子子を連ね た立面で, アンコール期のクメール建築には見られない独特の形 式を示すものである。東門の直ぐ脇の石板には格子状の花弁紋様 が，また水平長手の砂岩材を支える束状の砂岩材にも，植物紋様 が彫り込まれているが，これらの装飾は，他の祠堂の台座の彫刻 装飾と酷似しており，建造当初に内周壁も併せて建設されたこと は明らかである。

東門の内外では棟瓦敷きの床面が検出された。門の外側では，中 心軸から $1.8 \mathrm{~m}$ の幅で棟瓦敷きが確認されたため, 内一中周壁の東門 を連結するように全幅 $3.6 \mathrm{~m}$ の棟瓦敷きが参道状に延びていた様子が 復元される。

一方, 内周壁内の敷地では, 中央テラスの北東隅周辺のA-05 と B-05エリアの発掘調査により，ほぼ全面に煉瓦敷きの床面が広がっ

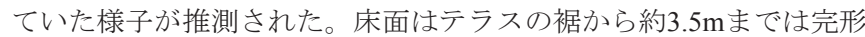
の棟瓦を対にして，縦横に直交するように丁寧に敷き詰められてい

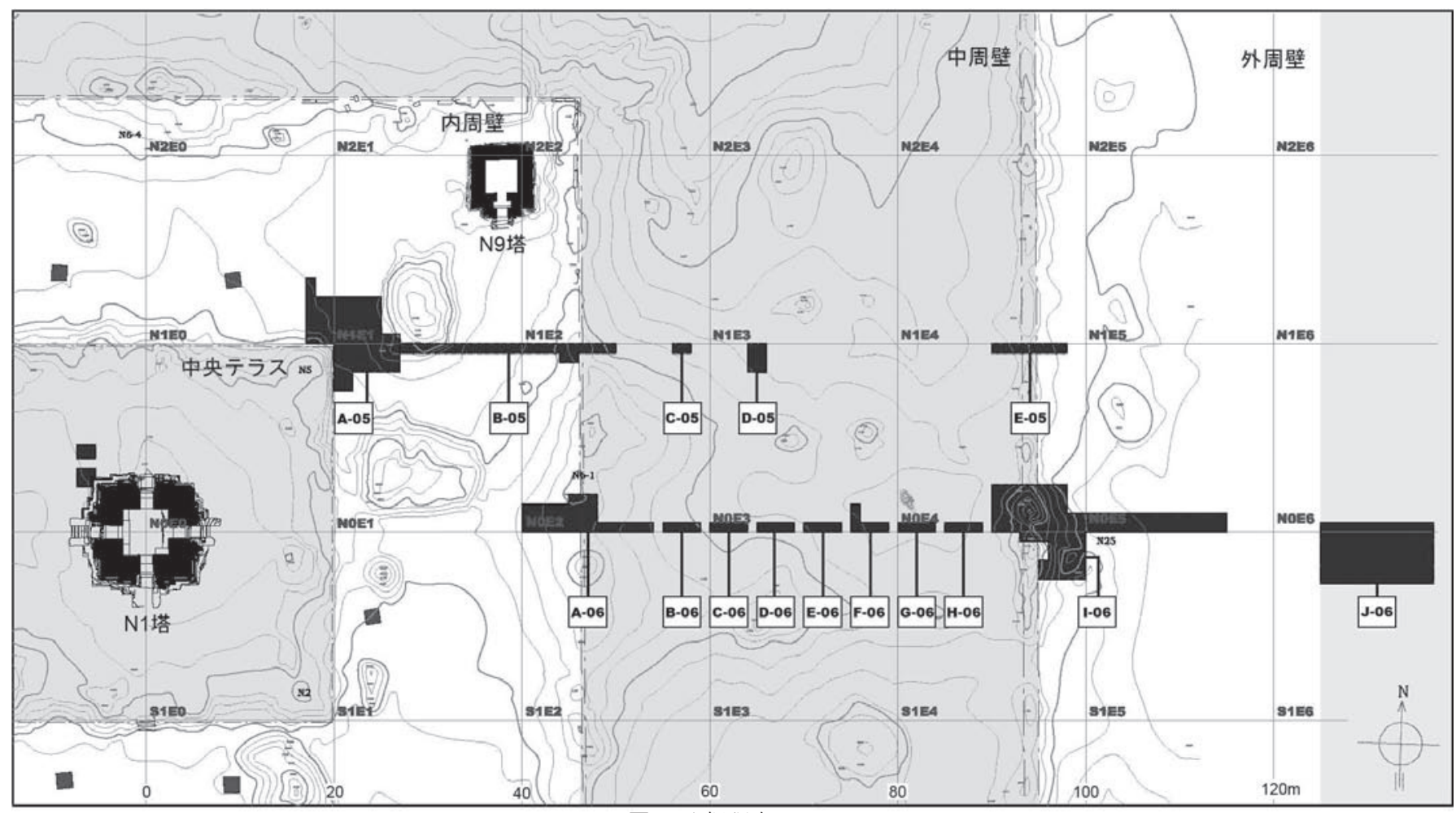

図2 発掘調査エリア 
るが，その外側では完形の煉瓦は殆ど認められず，半分ほどの大き さの煉瓦を不規則に敷き詰めた, 粗い仕事となる。また, 周壁の直 ぐ内側約 $1 \mathrm{~m}$ の幅では, テラス周辺と同様に丁寧に煉瓦を敷き詰めた 床面が検出されたため, 内周壁の内側には回廊状の歩面が周回して いた可能性が窥われた。

内周壁東門の外側に参道上の遺構が延びているのに対して, そ の内側では, 門の開口幅とほぼ同寸, つまり約 $2.8 \mathrm{~m}$ 幅でのみ煉瓦 敷きが出土した。ただし, この床面の北端は直線状に整えられて いないことから, 当初, 床面は周囲一面に広がっていたところを 後世に取り壊して, 主軸上の床面だけを参道状に残したものと推 測される。

こうした各建物間を連結する遺構が, 内周壁内からは他にも見つ かっている。B-05トレンチでは, 南北に走っているものと考えられ る周囲の床面から $30 \mathrm{~cm}$ 程高く持ち上げられた幅 $6 \mathrm{~m}$ の棟瓦遺構が検 出された。ちょうどN9塔への正面に位置しているため, N9塔へア クセス寸る通廊であったものと推測される。この通廊は, 参拝者 が歩く舗面となるにもかかわらず, 周囲の床面と比べても大変粗 い棟瓦敷きであることから, 建立当初に造られたものとは考えに くい。また, この通廊上の一部を掘り下げたところ, 周囲の床面と ほぼ同レヴェルで部分的に煉瓦材が検出された。つまり, 一面に棟 瓦敷きであった当初の床面上に通廊を増築した際に, 大半の煉瓦は 除去されたものの, 一部が取り残され, それが出土したものと考え られる。こうしたことから, この通廊遺構は後補のものである可能 性が窺われる。

内周壁東門付近では現地表面の約 $2 \mathrm{~m}$ 下方から, 当初遺構となる 棟瓦敷きの床面が検出されたが, その上層には複数の後補遺構が 積み重なるようにして確認された。それらの遺構は, 前身の遺構 を取り壊したり, あるいはそのまま上に重衫るようにして建造さ れていた。また, 再利用の棟瓦を外装材として, その内部は煉瓦 の端材を混ぜた土砂を締め固めただけの粗雑な造りであるため, そ れらの増改築の経過を子細に把握寸るのは困難である。こうした出 土状況ではあるが, あえて東門周辺における改変の過程を追うと次 のようになる。

最初の改変は小規模なもので, 東門の寸ぐ内側に棟瓦列によって 縁取りし，その内部に盛土されたステップが増築された。

その後, 東門の内側の床面を主軸上を除いて剥ぎ取ることで参道 状にし, さらにこの参道脇に棟瓦片を混入した土で突き固めた, 大 変堅固ではあるが粗雑な造りの, 背の低い遺構が敷設されたようで ある。この遺構は崩壊および変形が著しく, 把握は困難だが, 東門 の寸ぐ内側に $4 \mathrm{~m}$ 程の規模を持つ建物と, $50 \mathrm{~cm}$ 程の隙間をあけてさら に西側に配置された別の建物があったようである。

これと前後して, 東門内外の参道状遺構の脇には, 直径 $1 \mathrm{~m} の 大$ 穴
が掘り込まれた。東門から内側に $2 \mathrm{~m}$, 外側には隣接して, この大穴 は位置している。煉瓦敷き直下の基礎構造も掘り抜かれており, 穴 はかなりの深さに達するようであるが, 穴の底のレヴェルは正確に は確認されなかった。門全体に覆屋を後補した際の柱穴であったと

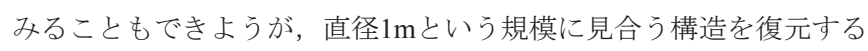
のは困難であり, この穴の機能は定かではない。

さらにこれらの増改築と前後して, 内周壁の外面に周回するよう にして取り付く, 厚さ $80 \mathrm{~cm} の$ 遺構が増築された。これもまた棟瓦と ラテライト片を混入した土を突き固めて, 外装面のみを再利用煉瓦 で粗く積み上げた造りであり，周壁とほぼ同等の高さに築かれてい る。周壁の外面に彫刻されていた彫刻装飾は, これによって覆い隠 されることになった。この改変とおそらく同時に, 東門を内側か ら封鎖する遺構が増築されたようである。門の敷居の上端より約 $50 \mathrm{~cm}$ 上に, この遺構の上面をな寸棟瓦積みが確認されている。こう した増築は伽藍の最内核を防衛する必要に駆られて付設された構造 物であるように推察されるが，そうした歴史的背景がこれまでに指 摘されたことはなく, 慎重な考察を要する。

こうした増改築の遺構の上層には, さらに内周壁内外を覆う棟 瓦の薄い層が認められる。この層位は水平には展開しておらず, 東門の付近でやや盛り上がっている。一部には煉瓦が規則的に敷 き詰められている箇所が認められることから, これもまた人工的 な遺構であるようだが, この段階に至っては, 地均しもされるこ となく, ただ煉瓦を敷き詰めるだけの，もはや些末な整備に過ぎ ないものであった。

\section{3 中周壁の改変}

中周壁はラテライト造によるもので, 各所とも崩壊が著しく, 建物上部の原型を留めているところは皆無である。ラテライトを 外装材としているが, その内部はラテライト片を詰め込んだだけ の粗い造りである。中周壁の東門からは, 前述の通り10世紀の碑 文K.436 と, 未完成で製作時代不詳のリンテルが出土している。遺 構の大半が土砂に埋没していた東門およびその周辺と（発掘エリア I-06), 東門から $20 \mathrm{~m}$ 北側の周壁部分（発掘エリアE-05）で発掘調查を 行い, 中周壁の構成を明らかにすると共に, 門と周壁内外に近接し て縦穴を掘り下げ, その基礎構造の把握を図った。

その結果, 周壁内外の縦穴からは, 周壁の床面下 $3.5 \mathrm{~m}$ の深さに達 するまで, 基礎構造が連続して確認された。図4は東門の中心軸から 北側に $4 \mathrm{~m}$, 東門と周壁の接合部で周壁内外を掘り下げた土層断面 図, 図5は中心軸から $20 \mathrm{~m}$ 北側での土層断面図である。いずれの地点 からも地表に一部露出している周壁築造時の床面レヴェルから, 深 さ約 $3.5 \mathrm{~m}$ の地山面に至るまで, 変化に富んだ構造が確認された。両 地点共に周壁の内外で構造が大きく異なっているが，16m離れた双
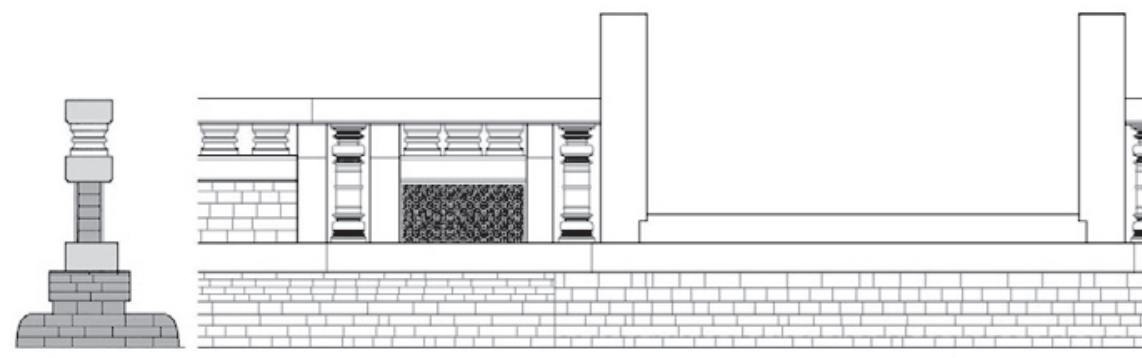

図3

内周壁東門, 東立面復元図と断面図 
方の層序は一部を除いてほぼ共通している。

東門付近の周壁直下と周壁内外の層序を表 1 〜 3 示す。

表1）周壁直下の構造

\begin{tabular}{|l|c|l|}
\hline 第 $\mathrm{a} 1$ 層 & $0-60 \mathrm{~cm}$ & $\begin{array}{l}\text { ラテライト材による基礎構造。壁体の外壁よりも形状が不揃いで粗 } \\
\text { い仕上げのラテライトが使用される }\end{array}$ \\
\hline 第 a2 層 & $60-85 \mathrm{~cm}$ & 煉瓦チップの混入した堅く締まったさ層 \\
\hline 第 a3 層 & $85-105 \mathrm{~cm}$ & 少量の煉瓦チプの混入した堅く締まった土層 \\
\hline 第 a4層 & $105-190 \mathrm{~cm}$ & 未加エの砂岩積み層 \\
\hline 第 a5 層 & $190-330 \mathrm{~cm}$ & 未加エのラテライトを密実に積み積み上げた層 \\
\hline 第 a6 層 & $330 \mathrm{~cm}-$ & 地山層 \\
\hline
\end{tabular}

表2）周壁外側の土層断面

\begin{tabular}{|c|c|c|}
\hline 第b1 層 & 床面上 & 表層の自然堆積土層 \\
\hline 第b2 層 & 床面上 & 周壁の崩落ラテライトが多く混入する堆積層 \\
\hline 第 b3 層 & 床 & $\begin{array}{l}\text { 棟瓦の端材を多量に混入する層。最終期の東門周囲の床面をなして } \\
\text { いたものと考えられる }\end{array}$ \\
\hline 第b4 層 & $0-55 \mathrm{~cm}$ & 炭化物と一部に少量の棟瓦チップが混入した土層 \\
\hline 第b5 層 & $55-85 \mathrm{~cm}$ & 棟瓦チップの混入した大変堅く締まった土層(第a2 層と同じ) \\
\hline 第 b6 層 & $85-180 \mathrm{~cm}$ & $\begin{array}{l}\text { 少量の棟瓦チップが混入した堅く締まった土層。3つに分層され, } \\
\text { 第二層は黒い斑点が混ざり，第三層はやや締まりが緩くなる。 }\end{array}$ \\
\hline 第 b7 層 & $180-195 \mathrm{~cm}$ & 煉瓦の端材を多量に混入する層 \\
\hline 第b8 層 & $195-330 \mathrm{~cm}$ & $\begin{array}{l}\text { 未加エのラテライトを密実に積み上げた層(第a5 層と同じ) } \\
\end{array}$ \\
\hline 第b9 層 & $330 \mathrm{~cm}^{-}$ & 地山層 \\
\hline
\end{tabular}

表3）周壁内側の土層断面

\begin{tabular}{|c|c|c|}
\hline 第 c1層 & 床面上 & 表層の自然堆積土層 \\
\hline 第 c2層 & 床面上 & 自然堆積土層 \\
\hline 第 c3層 & 床面上 & 周壁の崩落ラテライトが多く混入する堆積層 \\
\hline 第 c4層 & 床面上 & $\begin{array}{l}\text { 東門の上部構造の崩落前に堆積したものと推測される, 少量の煉瓦 } \\
\text { 片とラテライト片, 土器片が検出された土層 }\end{array}$ \\
\hline 第 c5層 & 床面上 & 棟瓦片と棟瓦チップが混入した土層 \\
\hline 第 c6 層 & 床 & $\begin{array}{l}\text { 棟瓦の端材を多量に混入する層。最終期の東門周囲の床面をなして } \\
\text { いたもの考えられる }\end{array}$ \\
\hline 第 c7層 & $35-80 \mathrm{~cm}$ & 大変堅く締まった土層 \\
\hline 第 c8層 & $80-115 \mathrm{~cm}$ & 棟瓦片を混入する堅く締まった土層 \\
\hline 第 c9層 & $115 \mathrm{~cm}^{-}$ & 直径 $30 \mathrm{~cm}$ 程の丸石を少数含む白い砂層 \\
\hline
\end{tabular}

東門から $20 \mathrm{~m}$ 北側の周壁内外を横断する発掘エリアからも，東門 付近と同様の基礎構造が確認されたが，以下に両地点間で異なる 点のみを略記する。

東門の遺構直下では，ラテライトのサイズが大きくほぼ上部遺構 と同じサイズであるのに対して (a1層)，北側の周壁直下では拳大程 の小型のラテライトが使用されている (d1層)。逆に下方の層から検 出された砂岩層の各部材は東門直下の方がやや小さく (a4層), 北側 周壁下では長さ $70 \mathrm{~cm}$ 以上と大材が利用されている(d4層)。しかし， そうした小異に拘泥しなければ，20m離れた両地点間での遺構直下

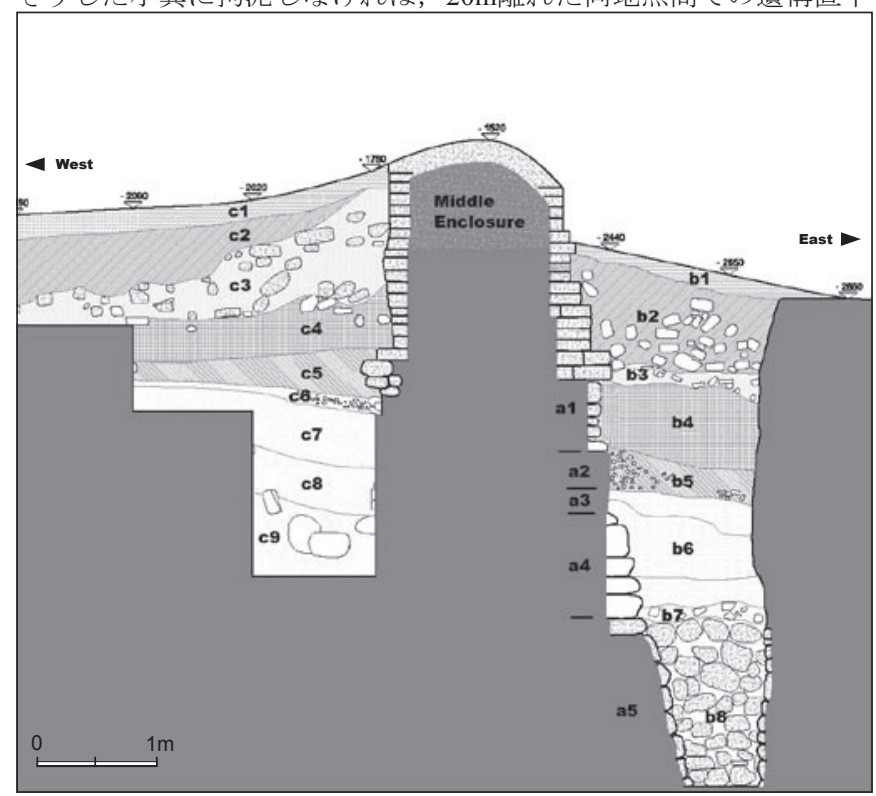

図4 中周壁内外の土層断面図（東門北側近傍）
の構造はほぼ同じであると考えて良い。

周壁外側の地下構造における両地点間では，東門の付近では床面 直下に煉瓦チップが混入する土層 (b4層) が認められるのに対して, 北側の周壁ではラテライトチップを混入する層 (e4層) となっている 点に相違が認められる。また，東門の床面下 $85-180 \mathrm{~cm}$ では煉瓦チッ プ混じりの土層(b6層)が検出されたのに対して，周壁の床面下80$160 \mathrm{~cm}$ からは頭大のラテライト部材を密実に積み上げた層 (e5層) が 検出された。また，その下層でも東門は床面下180-195cmにおいて 棟瓦の端材が多量に混入した土層 (b7層)により版築されているのに 対して，周壁の床面下160-180cmでは棟瓦の端材は含まれていない 土層であった (e6層)。このように，周壁の外側の地下構造は20m離 れた両地点間ではやや異なっている。

いずれにせよ，3m以上の厚さにおよぶこうした建材の変化に富ん だ基礎構造が，現存するラテライト造の中周壁を支持するためだけ の仕事であったとはいささか考えがたい。特に, 地下の組積構造と してラテライトと砂岩を使い分けているのは同一の基礎構造として は不自然である。こうした数種の構造を積み重ねていることに対す る解釈として，床面を嵩上げしてゆく増改築の過程を推測するの は，一つの妥当な見解であると考えられる。周壁内側の縦穴は十分 に掘り下げていないために，周壁内外での横断的な関係を把握する ことが難しいが，ここには二回の改変を推定することができる。

東門直下でこれを示すならば，第一期は砂岩の石積みであるa4層 が上部遺構の基壇となる段階で，この組積の足下とレヴェルをあわ せたb7層が周囲の床面をなす。a5層と b8層, またd5層とe7層はそれ ぞれ連続的な土層であり建物直下とその周囲とは連続的な地業とな っている。第二期はa2層とb5層が床面をなす時期である。周壁北側 では層の構造は異なるが，ラテライト積みの上端面にあたるd 2 層と e5層とがこれに対応する。a2層とb5層，またd2層とe5層はいずれも 連続的な層となってほぼ平滑な床面を造っている。第三期は地上に 一部露出して現存するラテライト造による周壁の構築段階であり, b3層とc5層が周囲の床面をなしていた。北側でも同様にe3層と 44 層と が周囲の床面をなしている。

周壁の内側では，外側と同位まで深く掘り下げていないため,

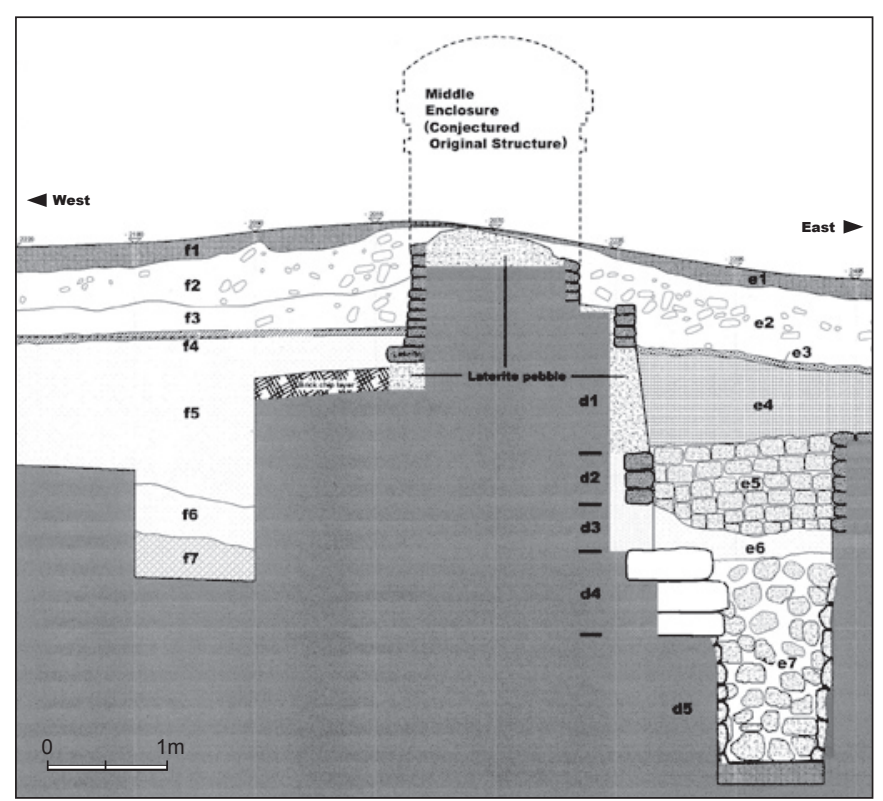

図5 中周壁内外の土層断面図（伽藍の主軸線から北へ20m） 
周壁直下とその内側の層位関係を特にその初期の段階と なる深層部で十分に把握できておらず, 今後の課題とな っている。

第一，第二期における上部建築の存在については定か ではないが，嵩上げを伴う増築時に取り壊されたことが 推測される。というのも, 現存する最上層の遺構, つま り第三期の建築に再利用部材が幾つか混ざっているため である。まず，東門の外側2段目の階段石の踏夕面には 扉の軸受けの穴が穿たれているが，この位置に扉が嵌め

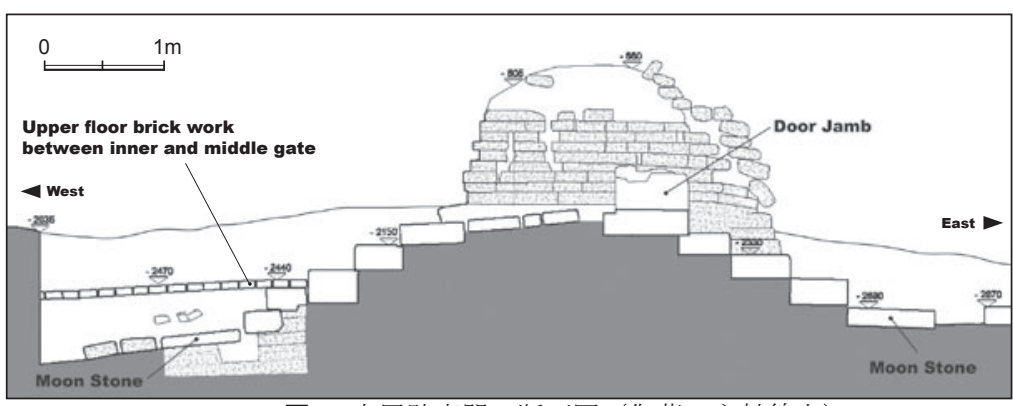

図6 中周壁東門の断面図（伽藍の主軸線上） 込まれていたことはありえず，これが再利用部材であることは明ら かである。また, 内側の階段石にも再利用されたことが確実な部材 が含まれている。前述したコロネット材がプレアンコール期の様式 であるのに対して, リンテルは年代不詳だが, 少なくともコロネッ 卜と同じ様式のものではなく, より後年の作であることが推測され ることは, やはりこのコロネット材が再利用部材であった可能性を 示唆している。

現存する東門が第三期目の遺構であるとすれば, この扉枠の碑文 に記された10世紀という年代は, 第三期となる改変の時代を示して いると考えうる証左となろう。

\section{4 内一中周壁間の参道の改変}

内周壁と中周壁それぞれの東門の間には，断続的に7つのトレンチ （B-06〜H-06）を設定した。トレンチからは地下 $30 \mathrm{~cm} の$ 深さから棟 瓦敷きの煉瓦の端材を乱雑に並べた粗い仕事による床面が検出され た。この床面の棟瓦を取り外して掘り下げたところ, さらに $30 \mathrm{~cm}$ 下 方からもう一層別の煉瓦敷きの床面が検出された。下層の床面は上 層のそれよりも仕事が丁寧であり, 使用されている煉瓦も整ってい た。中周壁東門の西側の階段では, 下層の床面をなす棟瓦敷きが, 階段石の上に乗り上げるように敷き詰められており，この床面の下 方より中周壁の二段の階段石とムーンストーンとが検出された（図 6）。これより, 最終段階となる中周壁の東門が建造された後に下層 の床面が構築され, またさらに時代が下って, 上層の床面が敷設さ れたことが明らかである。

この棟瓦敷きの広がりを調べるために，F-07トレンチの東端 $1 \mathrm{~m} を$ 北側に拡張したところ，主軸線より約 $1.8 \mathrm{~m}$ で煉瓦敷きが途絶えた。 よって, 主軸線を介して幅 $3.6 \mathrm{~m} の$ 煉瓦敷きであることが推測され, 内一外周壁東門間を連結する参道状の遺構であることが判明した。 また，この遺構の側面を掘り下げたところ，上層の棟瓦敷きの舗面 は, 棟瓦積みによって $60 \mathrm{~cm}$ ぼ゙持ち上げられて, 周囲からは一段高 くなっていることが確認された。
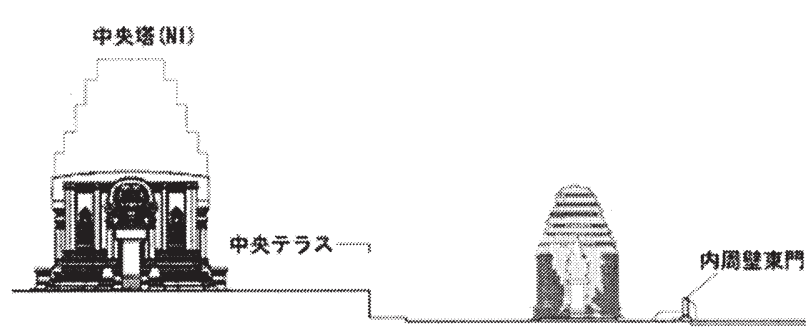

図7

伽藍東側の主軸線上にみる各遺構のレヴェル

\section{5 階段状テラス}

外周壁の大半は崩壊が著しく, 断続的にラテライト列が残存して いるに過ぎない。西辺と伽藍の東西主軸線との交点 (N36), および南 辺と主祠堂を通り主軸に直行する軸線との交点 (N35) には棟瓦造遺構 の痕跡が認められ, 扉周りを構成する砂岩部材も幾つか周囲には散 乱しているため, 外周壁の西門および南門をな寸遺構の痕跡である と推測される（図1）。今回発掘調查を行った外周壁東辺の中心軸線 上付近には, 未加工の大型砂岩材が一部で地上に露出していた。こ

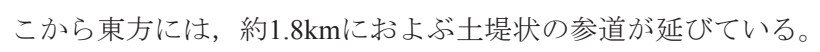

地上に露出していた砂岩材の周囲(J-06) を発掘調查したところ, 階段状に石材を敷き詰めた遺構が検出された。精霊神を祀る祠がこ の発掘エリアの寸ぐ北側に建てられており, そちら側一の拡張は控 えたために全体の平面構成は不明であるが，東西に $12 \mathrm{~m}$, 中心軸に 対して対称形の平面計画であれば南北に約 $10 \mathrm{~m}$ の平面規模であった とものと推測される。

砂岩は未加工であるが, 板状で長材が多い。参扯者のアプローチ の方向に直交するように, 部材は長手を南北に用いている。西側に 向けて徐々に上ってゆくように階段状に部材が配されており, 東西 両端で約 $90 \mathrm{~cm}$ 比高となる。石材のサイズは多様であるが，大きい ものでは長さ $3 \mathrm{~m}$ 以上のものも含まれ，基本的に中心軸線上に大型の 石材が使用される傾向がみられる。

この階段テラス状の遺構の西端レヴェルは, 中周壁東側の階段最 下段に配されるムーンストーンのレヴェルよりも約 $1 \mathrm{~m}$ 下がっている (図7)。このレヴェル差が中一外周壁間でどのように生じているのか は, 現時点では両地点間を横断する発掘調查を行っていないために 定かではない。テラス東端の最も低いレヴェルは, 中周壁に推測さ れた第一期の床面レヴェルとほぼ一致し, またテラス西端の最上レ ヴェルは, 中周壁の第二期床面レヴェルとやはりほぼ等しい(図7)。 よって, 中周壁の改変の推移と比較して考えるならば, 寺院中央に 向かって下るアプローチは想定し難いことから，テラスは中周壁の 第一期には存在せず, 第二期に建造された可能性が窥われる。ま た, 前述の通り, 外周壁の平面配置が方形を指向しているものの, 全体として若干の歪みをもち, 配置計画の精度の低さが窥われる事 実も, 外周壁およびテラスが寺院建立当初に建造された遺構ではな いことを示唆しているものと考えられる。 


\section{5. まとめ}

発掘調査により，いくつかの改変の痕跡が認められ，7世紀に当寺 院が建立された後にも，複数回に及ぶ改変が繰り返された様子が明 らかとなった。異なる地点で確認されたそれらの改変の過程を，時 系列に並べることは難しいが，出土した遺構の上下関係や，施工精 度の経時的な低下といった根拠にもとづき考察するならば，以下に 示す伽藍の推移が推定される。

(1)中周壁を嵩上げする第一回目の改変十外周壁東中央の階段状テ ラスの構築，(2)中周壁を嵩上げする第二回目の改変，(3)内一中周壁 間の参道下層床面の建設，(4)内一中周壁間の参道上層床面の建設， (5)内周壁内側のステップの付設，6)内周壁内側通廊脇の遺構の増 築，(7)内周壁内外の大穴の掘削，8内周壁外面に取り付く遺構の増 築十内周壁東門を封鎖する遺構の構築，乙して最後に，(9)内周壁周 辺を嵩上げする数度におよぶ改変。

これらの伽藍改変において, 唯一, 絶対的な建造時代の指標を 備えているのが，中周壁を嵩上げする第二回目の改変で，扉枠に 刻まれたK.436碑文の10世紀という年代である。碑文に記されるよ うに，この時に寺院は改宗され，ヴァジムカ像などの新たな彫像 も安置されたようである。ヴァジムカ像が高い芸術的水準を誇っ ていることからも，この時点での建築施工の精度は未だ一定水準を 保っていたものと考えられる。これに対して，その後に生じた一連 の改変では，仕事の質が大幅に低下している様子が窥える。こうし た事実から，アンコール朝の地方拠点として存続していたこの都城 は，少なくとも 10 世紀ごろまでは衛星都市の一つとして重要な位置 づけにあったものと推測される。さらに，20世紀初頭に撮影された 古写真には寺院内の祠堂にポストアンコール時代の木彫が配されて いる様子も認められ，アンコール時代が終焉を迎えた後にも，当寺 院では時に改変が加えられていたことが推測される。施工精度が著 しく低下した増改築の後期の段階は，こうした時代の仕事であった と考えられる。

こうした増改築の痕跡の中でも，伽藍の様相を特に大きく変えた のが，中周壁の嵩上げの改変である。現状では，この寺院は伽藍全 体をほぼ水平に展開する構成を呈しているが，この改変に考慮する と, 建立当初には中周壁は現存遺構よりも約 $2 \mathrm{~m}$ 低く位置していたこ とになり，伽藍全体では周囲が一段低く下がる立面構成であった様 子が復元される。現調查段階では，内一中周壁間でこの段差がどの ように吸収されているのか，また中一外周壁間の構造についてな ど，今後の追補調查が待たれる点も少なくない。こうした課題は残 されているものの，伽藍全体は一段高くなった中央テラスと内一中 周壁間の段差とによって，中心に向かって段台状に持ち上げられて いた建立当初の様子が推測され，全体としてさほど大きな高低差は ないものの，クメール複合寺院の一型式である堂山型の伽藍構成を なしていた可能性が指摘される。

クメール建築における堂山型寺院のおこりは，8世紀のアク・ヨ ム（Ak Yum）寺院に求められるのが一般的であるが，この推測か らは，その祖型をここプラサート・サンボー寺院にまで遡って位 置づけることもできそうである。つまり，最初期のクメール複合 寺院にして既に, 方形多重の平面や堂山型立面計画といった，後 年に大きく展開してゆく, クメール建築独自の伽藍構成の性向が 発現していると考えられるのである。伽藍規模に対する調査地区
が限定されている現段階でのこうした仮説に対して，今後も注意深 い検証を図りたい。

\section{謝辞}

本調査は1998年より開始された早稲田大学理工学部建築史研 究室とカンボジア文化芸術省の共同事業であるSambor Prei Kuk Conservation Projectの調査結果の一部である。当事業は，文化財保護 - 研究助成振興財団と住友財団より助成を受けて行われている。調查 はHin Sophorn氏（コンポントム州文化芸術局），Seng Kompheak氏 （シェムリアップ国立博物館），Chan Vitharong氏（文化芸術省）， So Sokuntheary女史と共同で行ったものである。文献読解において は佐藤桂女史，山崎冬馬氏の協力を得た。以上の方々に，心より感 謝申し上げます。

\section{註および参考文献}

註1) GOLOUBEW, Victor: Chronique: Sambor Prei Kuk, BEFEO, 27, pp.489-492, 1927.

註2) FINOT, Louis: Notes d'archeologie cambodienne, BCAI, pp.184-189, 1912

註3) 1961年に行われた発掘調査による出土品は, 現在プノンペン国立博物館 に収蔵されている。これらの出土品の再調査を，2007年に山本信夫と嶋 本紗枝の協力を得て行った。中国産陶磁に関寸る所見は山本信夫により ご教示いただいた。

註4）発掘調查はサンボー・プレイ・クック保全事業に上り，2004年から2006年 にかけて実施したものである。

註5) 下田一太, 中川武「遺構の分布と都市の中核区 クメール古代都市イーシ ヤナプラの構造に関する研究（その1）」『日本建築学会計画系論文集』 602, pp.211-218, 2006

註6) 下田一太他「サンボー・プレイ・クック遺跡群プラサート・サンボーに おける発掘調査（2004-2005シーズン）」『東南アジア考古学』26,pp.117145,2006

註7) CEEDĖS, George: Etudes Cambodgiennes XXXVI - Quelques precisions sur la fin de Fou-nan, BEFEO, 43, pp. 5-8, 1943-1946.

註8) CEEDĖs, George: Inscriptions du Cambodge, Vol.4, Paris, E. de Boccard (Collection des texts et documents sur l'Indochine, 3), pp.17-19, 1952.

註9) CEDĖS, George: Inscriptions du Cambodge, Vol.5, Paris, E. de Boccard (Collection des texts et documents sur l'Indochine, 3, pp.194-197, 1953.

註10) 金山好男「カンボディア・プレアンコール期のPura（城市）に就いて」『 南方史研究I』pp.3-26, 1959., 下田一太「カンボディア・プレアンコール 期のPura（城市）について 考古学的調査資料にもとづく一考察」東南ア ジア考古学会『東南アジアの都市と都城II』pp.41-55, 2006.

註11) CEDĖS, George: Inscriptions du Cambodge, Vol.4, Paris, E. de Boccard (Collection des texts et documents sur l'Indochine, 3), pp. 20-24, 33-34, 1952.

註12) SHIMODA, Ichita: Frühe Khmer-Tempel und die Symbolik be der Verehrung der Naturgeister, Orientierungen, pp.25-49, 2007.

註13) 前掲書註1.

註14) DUPONT, Pierre: La statuaire préankorienne, Ascona, Artibus Asiae, 15, pp.150$155,1955$.

註15) これまでに復元調査を終えた台座は，プラサート・サンボー内では, N1/N7/N8/N10/N11/N14-2/N22塔である。

註16) BOISSELIER, Jean: Une statue féminine inédited du style de Sambor, Arts Asiatiques, 2(1), pp.18-34, 1955., Dupont, op. cit., pp.147-155.

註17) 一組の台座は過去に室内に散乱していたが，もう一組は2005年に実施し た塔内の発掘調查によって発見された。

註18) 前掲書註14, pp.156-162.

註19) LE BONHER, Albert: Un Śiva inédit du style des Khleang, Arts Asiatiques, 30, pp. $179-204,1974$

註20）N7塔内の台座は2003年から2004年にかけて実施した発掘調査により，遺 失部の大半が発見され，復元されている。下田一太他「サンボー・プレ イ・クック N7塔室内の基礎構造 プレ・アンコール期クメール建築の研 究 $(X) 」 『 日$ 本建築学会大会梗概集』pp.533-534, 2004

註21) 前掲書註1, Masson, A: Le dégagement de Sambor Prei Kuk (1927-1929), Extrême Asie, Revue indochinoise 36, pp.535-537, 1927

註22) GROSLIER, Bernard-Philippe: Unpublished material in EFEO, 1962.

註23) GROSLIER, Bernard-Philippe: Introduction to the ceramic wares of Angkor, in Khmer Ceramics 9th-14th century, in D. Stock (ed.), Southeast Asian Ceramics Society, pp.9-40, 1981

註24) 前掲註3.

註25) クリアランスは，国連世界食糧計画によるFood for Workプログラムによ る支援事業の一環として地元住民の参加の下に行われた。

註26) 下田一太他「サンボー・プレイ・クックN1塔の改変-プレ・アンコール期 クメール建築の研究 (VII)」『日本建築学会大会梗概集』pp.161-162, 2003

註27) PARMENTIER, Henri: L'art khmér primitif (2 Vol.), Paris, PEFEO 21-22, p. 359, 1927.

2007 年 12 月 10 日原稿受理，2008年 3 月 3 日採用決定） 